\title{
ROME AT SEA: THE BEGINNINGS OF ROMAN NAVAL POWER*
}

Between the Battle of Mylae in 260 BC (when Rome defeated Carthage off the north coast of Sicily) and the Battle of Myonnesus in 190 (when Rome defeated the Seleucid navy off the west coast of Asia Minor), the Romans established naval domination over the whole Mediterranean. Scholars generally believe, for quite good reasons, that this process of naval aggrandisement began abruptly, the Romans having previously taken no interest in the sea. That, after all, is what Polybius quite clearly says.

\section{Polybius and a legend}

The contention here, however, is that Rome did not 'suddenly' become a naval power in the early years of its first war with Carthage, but that it had been moving inexorably in that direction since at least 314 BC. ${ }^{1}$ My purpose is not to quibble about chronology but to reconstruct an important aspect of Roman behaviour towards the outside world in the crucial two generations prior to the First Punic War. Historiographically speaking, this article can be considered another foray in the long-running and just wars against both the 'defensive imperialists' and the 'international relations' theorists. The implications of what I shall be saying is that Rome was already a startlingly predatory and adventurous state by the period 314-305, and that, while the

\footnotetext{
* All translations from the Greek and Latin are my own.

1 'Suddenly' is the characterization given in M. Leigh, 'Early Roman Epic and the Maritime Moment', CPh 105 (2010), 265. A. Burnett and M. H. Crawford, 'Coinage, Money and Mid-Republican Rome', AIIN 60 (2014), 263, n. 68, hold that Rome's naval activities before the First Punic War were 'rather minimal' - the normal view. I am attempting in this article to make a case somewhat marred by C. Steinby, The Roman Republican Navy. From the Sixth Century to 167 B.c. (Helsinki, 2007). P. de Souza, 'Polybius on Naval Warfare', in T. Howe, E. Garvin, and G. Wrightson (eds.), Greece, Macedon, and Persia (Oxford, 2015), 189-90, is sceptical of Polybius' primary claim but does not examine Rome's earlier behaviour.
} 
Senate took a deep breath (as well it might) before first engaging with Carthage, it was very nearly ready to do so by 264 .

The scholars who believe that Rome was not a 'naval power' before the First Punic War are of course perfectly right if they mean that it was never in that period a Mediterranean naval power. But I shall take it that Rome was already a naval power if it could impose its will by largely naval means in places outside Latium; and if it could form a meaningful and active 'friendship' with the naval state of Rhodes, as we now securely know happened, in about 306 BC. There is a 'glass half-full, glass half-empty' element in this dispute. But there is also a real and historically important disagreement.

A huge doxography is not necessary. For convenience I will take as my starting point the admirable Livy commentary of Stephen Oakley, who tells us that 'our (no doubt incomplete) sources record only two occasions during the fifty years before the First Punic War in which the Romans were involved in naval activity', namely the raid on Pompeii in 310/309 and the fight at Tarentum in $282 .{ }^{2}$ I shall attempt to show both that the sources are not as 'incomplete' as they may appear, and also that scholars have failed to take sufficient account of their incompleteness, which requires us to use our informed imaginations and weigh reasonable conjectures about things that are likely to have happened.

J. H. Thiel, the old authority on early Roman naval power, concluded that Rome was uninterested in naval power prior to the early years of the First Punic War. ${ }^{3}$ As Oakley remarks, various scholars soon challenged that view, citing the alleged Roman colonization of Sardinia, the attempted Roman colonization of Corsica, a reference in Diodorus Siculus to an Etruscan pirate with the Latin name Postumius, Rome's treaties with Carthage, and a Roman treaty with Tarentum of unknown date recorded by Appian. Yet all this, says Oakley, 'adds up to little'. He considers the story in Polybius 1.20 to the effect that the Romans were completely innocent about naval warfare to be a 'legend' (many other scholars have come to the same conclusion) but at the same time 'eloquent', meaning apparently, if I have understood him correctly, that it was nonetheless largely true. ${ }^{4}$ Oakley

${ }^{2}$ S. P. Oakley, A Commentary on Livy, Books VI-X. Volume III. Book IX (Oxford, 2005), 394.

3 J. H. Thiel, A History of Roman Sea-Power before the Second Punic War (Amsterdam, 1954).

${ }^{4}$ Oakley (n. 2), 394. 
wrote all this à propos Livy's statement that in 311 a tribune successfully proposed a law that the Roman people should appoint duumviri navales classis ornandae reficiendaeque causa, ("two naval commissioners in charge of preparing and repairing the fleet') (notice that they were to restore as well as prepare a fleet).

Later I shall step back to the mid-fourth century, but we must start by looking at the crucial passage in Polybius 1.20 just mentioned. The historian says that in 263 the Carthaginians 'commanded the sea' (1.16.7), and that until 261 the Romans 'had never even given a thought to the sea' (1.20.12); in that year they at last 'took urgent steps to embark on the sea with the Carthaginians' (1.20.7). But his account is, in the first place, somewhat incoherent: on the one hand, he dates the beginnings of Roman naval construction to 261 , on the other, he says that in 264, in order to cross to Messina, the Romans borrowed ships from the socii navales ('naval allies'), were attacked by the Carthaginian navy, and captured the Carthaginian ship which became a model for their entire fleet (1.20.13-16). Did they then keep this ship for three years without making use of it? In the second place, other sources flatly contradict Polybius' claim that it was only in 260 that the Romans put warships to sea: Polybius' contemporary, the historian L. Piso, said that in order to fight against King Hiero of Syracuse Rome had already put together a fleet of 220 ships in forty-five days (Pliny, $N H 16.192^{5}$ ) - no doubt a textual error and/or a major exaggeration ${ }^{6}$ - and this must have been in 263, if it happened at all. In any case, this was a story radically different from Polybius' narrative.

Add in the plainly legendary elements in Polybius' account (learning to row by practising on land; $1.21 .1-2$ ), and you have good reason to suspect that his main story reproduced a patriotic Roman fiction, presumably taken over - as many have suggested - from Fabius Pictor, who led Polybius up the garden path on other occasions too. This patriotic fiction will have been aimed at showing both Rome's innocence (far be it from them to have built up a capacity for fighting a naval war) and their extraordinary adaptability (a recurrent Polybian theme: compare 6.25.11).

\footnotetext{
${ }^{5}$ Fr. 31 Cornell.

${ }^{6}$ This would have required a well-organized workforce of many thousands of men. G. Forsythe, The Historian L. Calpurnius Frugi (Lanham, MD, 1994), 361-2, speculates about the origins of Pliny's figures.
} 


\section{Ostia, Antium, infrastructure, resources}

It is impossible to gain a clear idea of what was in Roman minds when Rome first established secure access to the sea by fortifying Ostia somewhat before 350 BC and by setting up a citizen colony at Antium in 338, then another at Tarracina in 329. But these coastal sites could certainly not have been defended effectively without some warships. The treaty with Carthage of 348 (Polybius' 'second treaty' in my view ${ }^{7}$ ) makes no allusion to official Roman naval forces, but that is easy enough to explain. In any case, these events raise the complicated question of whether it is possible to distinguish naval warfare from piracy in fourthcentury BC Italy. I have suggested elsewhere that the Roman aristocracy may for a time have been content to leave the risks and profits of maritime escapades to private enterprise. ${ }^{8}$ That would be congruent with the difficulty that some Greeks experienced in this period in telling the difference between Etruscans and pirates; scholars have sometimes suggested in fact that Greek Turrhenoi/Tursenoi meant not 'Etruscans' but 'pirates'.

In any case we know that the city of Rome possessed docks of some kind, navalia, by the year 338 (Livy 8.14); that was where Rome took the ships that they had captured from the Antiates. This fact is admitted but rhetorically played down by Thiel and his followers, but it is vitally important because it implies that Rome was already in possession of the technology and basic infrastructure necessary for building a serious naval force. ${ }^{9}$ And if we are going to find a plausible date for the treaty that Rome supposedly made with Tarentum (the only source is Appian, Sam. 7.1, who in the context of 282 BC calls the treaty ancient), in which Rome agreed not to sail (that is, with warships) beyond the Lacinian promontory (on the east coast of Italy's toe), the best bet, as Oakley himself has shown, is the period 332-330. ${ }^{10}$

The next question to consider is what an ancient state needed in order to build and maintain a fleet. We can divide these requirements into three main groups: shipbuilders, raw materials, and crews

\footnotetext{
${ }^{7}$ That is to say, the treaty described in Polybius 3.24.

${ }^{8}$ W. V. Harris, 'Roman Warfare in the Social and Economic Context of the Fourth Century B.c.', in W. Eder (ed.), Staat und Staatlichkeit in der frühen römischen Republik (Stuttgart, 1990), 500 .

${ }^{9}$ Thiel (n. 3), 48-9.

${ }^{10}$ S. P. Oakley, A Commentary on Livy, Books VI-X. Volume II. Books VII-VIII (Oxford, 1998), 681, n. 1 .
} 
(including captains and navigators). (We should also think about other practical factors such as the provisioning of crews on campaign and the parking of ships when they were not in use.) The point here is that none of these resources could be assembled quickly, and also that, barring the sort of massive losses of crew that sometimes happened during the First Punic War, they are not likely to have been dispersed quickly either. I came to appreciate the complications involved in gathering the needed raw materials when I was working recently on ancient ship construction. ${ }^{11}$ It is not only a question of locating and transporting the right kind of timber; ropes, sails, metal tools and fittings, and pitch are all needed in great quantity. ${ }^{12}$ In this context we should observe that Polybius radically undermines his own story when he says that in 261 Rome built 120 ships (1.20.10), because his claim is that 'their shipwrights were absolutely inexperienced in building pentereis' (that is to say, quinqueremes). ${ }^{13}$ The very strong, and indeed crucial, implications are, first, that trained Roman shipwrights existed, and second, that they knew perfectly well how to build oldfashioned triremes as distinct from up-to-date quinqueremes.

\section{Years of change, 314-305}

The naval context in the 320 s and 310 s is a complicated one. Every western Greek city of any size probably had a few warships, coastal Etruscan cities presumably the same. Carthage loomed in the distance, but was only three days' sailing away from the mouth of the Tiber. It possessed the largest navy in the western Mediterranean. To judge from Carthage's ship-sheds, as well as the textual evidence, its home fleet normally seems to have contained 170 to 180 vessels - scary enough but not invulnerable. ${ }^{14}$ One wonders how much information

${ }^{11}$ See W. V. Harris and K. Iara (eds.), Maritime Technology in the Ancient Economy. Ship-Design and Navigation (Portsmouth, RI, 2011).

${ }^{12}$ Here I can quote a writer of this period, Theophrastus (Hist. pl. 5.7.1): 'fir, mountain pine and cedar are the standard ship-timbers. Triremes and long ships [i.e. warships] are made of fir because it is light, while merchant ships are made of pine because it does not rot. Some people, however, make their triremes of pine also, because they are short of fir....These woods are used for the main timbers, but for the trireme's keel oak is used....They make the cutwater...and cat-heads, which require special strength, of ash, mulberry or elm'.

${ }^{13}$ For a succinct account of the probably differences between triremes, quadriremes, and quinqueremes, see P. de Souza, 'Naval Forces', in P. Sabin, H. van Wees, and M. Whitby (eds.), The Cambridge History of Greek and Roman Warfare (Cambridge, 2007), i.357-61. Syracuse and Carthage seem to have led the escalation in ship size, leaving the Romans and others behind.

${ }^{14}$ See N. Pilkington, The Carthaginian Empire, 550-202 BCE (forthcoming). 
Romans or other Italians had on that subject. Meanwhile, Rome had as yet scarcely any socii navales - only Neapolis (and that only from 326).

The period from 314 to 305 was an extraordinary one in Rome's external affairs. Here I will emphasize those events that had naval implications. Consider the foundation of the colony at Luceria in 314, a landlocked site on the far side of Samnite territory. ${ }^{15}$ Should we believe that the colonists got there by marching right across Samnium? Scholars have paid scant attention to topography in this case. Is it not much more likely that Roman forces and colonists arrived at least in part by sea, the sea being only about 50 kilometres from the site? It was in any case a bold initiative. Even more instructive is the foundation in 313 of another Latin colony at Pontiae (Ponza), a site that was only viable if the Roman state and/or wealthy citizens committed themselves to a certain degree of maritime investment; otherwise it was vulnerable to the first squadron of Etruscan - or, for that matter, of Carthaginian - ships that might appear. ${ }^{16}$

Meanwhile Rome was taking equally bold steps on land: for example, the attack on the Marrucini on the east coast in 312 (Diod. Sic. 19.105.5). ${ }^{17}$ The following year saw the appointment of the first duumviri navales. Some scholars suppose that this was only an occasional office, but that is not what Livy seems to have thought (9.30.3-4). ${ }^{18}$ Nor, contrary to common opinion, do we have any notion as to the number of ships they were supposed to make ready, for the information we have about their activities 130 years later refers to a completely different situation in which the Mediterranean was a Roman lake marginally troubled by corsairs. ${ }^{19}$ The same year, 311, also saw both the doubling of the number of legions and the beginning of the most ambitious assault on the Etruscans since the siege of Veii more than seventy years earlier. I have no doubt that the Etruscan campaigns of 311-308 were mainly land campaigns, but (speaking of incomplete sources) it would be absurd to imagine that Rome could be at war with almost all the nomen Etruscum (Livy 9.41.6) without taking thought for naval

${ }^{15}$ I leave aside here questions about the topography of Forentum and Nerulum (Livy 9.20).

${ }^{16}$ Harris (n. 8), 500-1.

${ }^{17}$ See Oakley (n. 2), 345-6.

18 duo imperia eo anno dari coepta per populum...unum, ut tribuni militum... alterum, ut duumviros navales classis ornandae reficiendaeque causa idem populus iuberet ('Two commands began that year to be conferred by the people...one, so that the military tribunes...the other so that the people were to appoint two commissioners to take charge of the preparing and repairing of the fleet').

${ }^{19}$ Livy 40.18.7-8, etc. Appian, Sam. 7, is equally irrelevant on this point, pace Oakley (n. 2), 395. See further below. 
conflict. Indeed this may have been precisely the reason why Rome made a long-term truce with Tarquinia in $308 .{ }^{20}$

In 310, meanwhile, a Roman commander, 'quem senatus maritimae orae praefecerat' ('whom the Senate had appointed to command the sea coast'), was despatched with a naval force to Campania and reached at least as far down the coast as Pompeii and the territory of Nuceria (Liv. 9.38.2-3). The main force seems to have consisted of socii navales, which on this occasion must mainly refer to Neapolitans. ${ }^{21}$ Rome attacked Umbrians for the first time in 310 or 308.22 The next time we catch sight of Romans at sea is in 307 and/or 306, when they campaigned in the far south-east, in Apulia and the Sallentine peninsula and it is impossible to imagine that they did not use ships to transport and protect their forces in the latter area in particular. In any case, it was after a remarkable decade of aggressions that, in 306 or 305, Rome established friendship with Rhodes.

\section{Rhodes and pirates}

In the context of $167 \mathrm{BC}$, Polybius notoriously wrote that 'though for nearly 140 years [prior to 167] the people of Rhodes had shared with the Romans in the most glorious and finest achievements (ton epiphanestaton kai kalliston ergon), it had not yet made a formal alliance with them' (30.5). ${ }^{23}$ Such language - 'glorious and finest achievements' makes one think, as virtually all recognize, of military cooperation of some kind. And this is obviously not a reference to Roman-Rhodian cooperation in the second century. Hatto Schmitt in particular showed long ago that friendly contact between the two states at the end of the fourth century was perfectly credible; he pointed out, among other things, that it was just in this period around 300 that the Rhodian traders returned in some force to Magna Graecia. ${ }^{24}$

\footnotetext{
${ }^{20}$ But Rome's main interest in this three-year series of campaigns was in the Tiber Valley; for the events in question, see W. V. Harris, Rome in Etruria and Umbria (Oxford, 1971), 50-1, and Oakley's commentary on the Livy passages in question.

${ }^{21}$ Oakley (n. 2), 396, does not convince me that this expression can normally refer to Roman citizens.

${ }^{22}$ See G. Bradley, Ancient Umbria (Oxford, 2000), 107-17.

${ }^{23}$ The other sources are Livy 45.25 (he sees the relationship as one of amicitia) and Cassius Dio fr. 68 .

${ }^{24}$ H. H. Schmitt, Rom und Rhodos (Munich, 1957), 36-7.
} 
Since Schmitt wrote, the evidence has continued to accumulate: we now know for example that there were Rhodian amphorae at Pompeii in the third century BC. ${ }^{25}$ Finally, in 1983 an inscription was published (SEG 33 [1983] no. 637) that virtually guarantees that Polybius was right about the Rome-Rhodes friendship, though no one realized it for a long time because of the errors of the original editor. It dates at the latest from the second quarter of the third century BC, as both the established experts on the chronology of Rhodian inscriptions known to me agree; ${ }^{26}$ and, though it is badly damaged, it makes it clear that at that time Rome and Rhodians already counted each others as 'friends'. ${ }^{27}$

Does a Roman relationship c.306 make sense from a Rhodian point of view? 305/304 was the time of the great siege of Rhodes by Demetrius Poliorcetes. Before the siege began, Rhodes was already, as Diodorus says, 'strong in sea power' and it had 'independently waged war on behalf of the Greeks against the pirates' (20.81). At the same time, it was in need of all the friends it could find. Of course the Rhodians could not have expected before the siege, or in the years immediately afterwards, that Rome could help them against the Hellenistic kings. There was, however, a definite Rhodian interest, both before and after, that went well beyond the peaceful pursuit of trade. A plausible common interest would have been the suppression of pirates, based on some sort of mutual agreement as to who should be counted as a pirate. ${ }^{28}$

We need not decide here whether 'pirate' was in these times simply a label that was attached to merchants who came from places you happened not to like, ${ }^{29}$ but there is nothing at all unlikely in supposing that Rome was becoming far more interested, in the years 314-306,

${ }^{25}$ M. Bonghi Jovino, Ricerche in Pompei. L'insula 5 della Regio VI dalle origini al 79 d.C. (Rome, 1984), 280. For other evidence published after Schmitt, see M. W. Frederiksen, Campania (London, 1984), 108.

${ }^{26}$ C. Crowther, personal comm. (cf. W. V. Harris, 'Quando e come l'Italia divenne per la prima volta Italia?', Studi Storici 48 (2007), 316-17); N. Badoud, 'Rhodes et les Cyclades à l'époque hellénistique', in G. Bonnin and E. Le Quéré (eds.), Pouvoir, iles et mer. Formes et modalités de l'hégémonie dans les Cyclades antiques (VII s. a.C-III s. p.C.) (Bordeaux, 2014), 120, n. 40. For the latter's comprehensive work on the chronology of Rhodian inscriptions, see N. Badoud, Le Temps de Rhodes (Munich, 2015).

${ }^{27}$ V. Kontorini, 'Rome et Rhodes au tournant du IIIe s. av.J.-C. d'après une inscription inédite de Rhodes', fRS 73 (1983), 31-2.

${ }^{28}$ For the intensification of piracy in the second half of the fourth century, see M. Giuffrida Ientile, La pirateria tirrenica. Momenti e fortuna (Rome, 1983), 79-90.

${ }^{29}$ See H.-U. Wiemer, Krieg, Handel und Piraterie. Untersuchungen zur Geschichte des hellenistischen Rhodos (Berlin, 2002), esp. 111-17. 
in securing both its commercial vessels and its war vessels to the east as well as to the west of Italy's toe. The strait of Messina was growing steadily more important to them.

Most of the Etruscans were a common enemy. We know from the Rhodian inscription $S I G^{3} 1225$ that the Rhodians took action in the west against Etruscan pirates at some date in this general period (the inscription leaves it frustratingly uncertain whether this was in Italy or in Sicily). ${ }^{30}$ The last specific date when we hear of precautions being taken against Etruscan piracy is in a Delian inscription referring to the year $298 .{ }^{31}$ It is no counter-argument that the Romans had been slow to interfere with piracy, ${ }^{32}$ for in this period it was natural that they would not rush to deal with the freebooting of their own people while acting against identical behaviour when it was carried out by others.

What then were the 'very glorious and fine deeds' that the Romans and Rhodians allegedly performed together at the end of the fourth century? The obvious, though not necessarily correct, answer, adumbrated by Schmitt, is that they took some joint action against people they represented as pirates, probably Etruscans. (Thus there was plenty of sarcasm on display when Demetrius Poliorcetes sent some Italian pirates he had captured to Rome [Strabo 5.232], quite probably while he was on the Macedonian throne [294-287]. His accompanying message said, in part, that he did not think it was appropriate for the same people to rule over Italy and send out expeditions of pirates. ${ }^{33}$ )

\section{Rome and Magna Graecia in the 280s and 270s}

We know little about Roman history between 292 and 264 except for some semi-legends - the Secession of the Plebs, the frugality of

\footnotetext{
${ }^{30}$ The man commemorated had made an expedition to ']lian' (line 4). The inscription dates from the third century, but opinion is divided between the first and the second half: see Wiemer (n. 29), 131.

${ }^{31} I G$ XI.148, line 73.

${ }^{32}$ As claimed by R. M. Berthold, Rhodes in the Hellenistic Age (Ithaca, NY, and London, 1984), 237, n. 15.

${ }_{33}$ Another plausible occasion of Roman-Rhodian cooperation is the little-known campaign of 302, in which a Roman consul or dictator expelled the Spartan prince Cleonymus from Thurii and places in the Sallentine peninsula (which is a geographical contradiction that has given rise to extensive commentary) (Livy 10.2). This is, of course, speculation (though there was certainly no love lost between Sparta and the Rhodian democracy). But the whole incident is deeply obscure. Moreover, Livy's two versions of the story differ: in one the consul seems to have operated on land only (10.2.2); in the other it may be implied that the dictator arrived with ships (10.2.3).
} 
C. Fabricius, and so on - and except for what we can glean from Livy's Periochae (chapter headings) and from the Fasti Triumphales, themselves fragmentary. The major exception to our terrible lack of information is, of course, the war against Pyrrhus. Before coming to that event, however, some comments are needed on the strife between Rome and Tarentum in 282, when a small Roman naval expedition ran into grave trouble off the Tarentine coast. ${ }^{34}$ It appears from all the sources that Rome and Tarentum were at peace at the beginning of the story (though the Tarentines had ample reasons to be suspicious of Roman intentions). Protestations of innocence coming from the Roman side are naturally very suspect, but it is evident that the small force in question had not in fact been sent out to capture Tarentum. ${ }^{35}$ Moreover, it is likely to have been no more than one element in Rome's naval resources at the time, for the Romans cannot possibly have sent a large part of their navy to Tarentum, given all the enemies and potential enemies they had on the Tyrrhenian side of the peninsula. There must have been still other warships in reserve.

What of the socii navales in the period? Scholars who interest themselves in this period seem generally to suppose that Rome relied for its naval forces on specially designated allies, but most of those alliances only date from about 280; that will apply to Rhegium and Locri. Naples is the only place that is known to have had a maritime obligation to Rome well before that date, and while it is true that Livy on one occasion refers to other allies 'eius orae' ('on that coast' - that is to say, in the neighbourhood of Naples; 36.42.1), the ships that Rome is known to have obtained in that area were merely 'open ships' (ibid.), not major warships. ${ }^{36}$ Thiel, in order to account for the fourthcentury evidence for a Roman navy while maintaining his theory that the Romans came to the First Punic War wholly unready for naval warfare, hypothesized that a new period began in or around 278 with the Romans now being able to depend on the socii navales for all their

${ }^{34}$ I leave aside here the help that Rome gave to Thurii c.285 (Livy, Per. 11; Plin. HN 34.32). But see the passage of Appian referred to in n. 35.

${ }^{35}$ App. Sam. 7.1 says that one Cornelius was sent with ten decked ships to inspect Magna Graecia. According to Dio (fr. 39.2), Tarentum was plotting war against Rome, so a Roman 'nauarch' was sent on a mission to the Greek city (fr. 39.4, 39.5). The Tarentines successfully attacked this Roman force and then, according to Appian, proceeded to expel the Roman garrison from Thurii.

${ }^{36}$ Who these other allies may have been is not clear: the nearest town with an attested treaty obligation to provide Rome with warships was Paestum (Livy 26.39 and 27.10, where, however, there is some confusion, since Paestum was by the dates in question a Latin colony). 
naval needs. ${ }^{37}$ I will attempt to show below that that is an implausible story.

What can we learn about Rome's naval capabilities from the sources about Pyrrhus' invasion of Italy? Perhaps not very much, but a brief speculation may be worthwhile. Consider how Pyrrhus behaved after arriving in Italy with a considerable naval force and after defeating the Romans at Heracleia in 280. All his further activities against Rome were carried on by land (battles at Capua and Asculum). Why was there no advance by sea? Of course there were some socii navales of the Romans in the way, but perhaps the Tyrrhenian coast of Italy was also defended by a serious Roman naval force. It was easier for him to transfer his attention to Sicily.

It can certainly be argued that when Rome made a treaty with Carthage in 279 (Polyb. 3.25.1-5), its terms may imply that Carthage was the stronger naval power. ${ }^{38}$ However, it is not in any case to be doubted that this was so - and it may possibly be that the imbalance of obligations was a result of Carthage's needing the treaty more than Rome did. ${ }^{39}$

Did Rome then have a significant navy in the 270 s and early 260 s? According to Thiel, Rome 'transfer[red] the whole naval job to strangers' in this decade. ${ }^{40}$ That is most unconvincing. It could only be true if the Romans placed deep trust in Rhegium, Locri, Tarentum, Syracuse, and Carthage, all of which they in fact had good reason to distrust. ${ }^{41}$ It is true, I will admit, that the simultaneous founding of Cosa and Paestum in 273 might theoretically be taken as simply a precautionary measure vis-à-vis Carthage, though that is not how I would prefer to see them. But the most significant act of naval preparation that took place in the 270s was the acquisition of half the Sila Forest in Bruttian territory:

37 Thiel (n. 3), 32.

38 ' ... no matter which requires help, the Carthaginians are to provide the ships for transport for the outward journey and the return, and each side shall provide supplies for its own men. The Carthaginians shall provide the Romans with help by sea too, if there is need, but no one shall compel the crews to land against their will.' There is no need to discuss the textual problems here.

39 'The most likely explanation of the historical context of this treaty is that the Carthaginians feared a Roman peace with Pyrrhus': F. W. Walbank, A Historical Commentary on Polybius. Vol. 1 (Oxford, 1957), 349.

${ }^{40}$ Thiel (n. 3), 32.

${ }^{41}$ Admittedly, in 264 a Roman consul chose to trust Tarentines, Locrians, Eleans, and Neapolitans to carry his troops across the Strait (Polyb. 1.20.14). 
the Bruttians handed over to them one half of their mountainous district called Sila, which is full of timber suitable for the building of houses and ships and every other kind of construction...For much fir grows there, towering to the sky, much black poplar, much pitch pine, beech, stone pine, oak, and ash. (Dion. Hal., Ant. Rom. 20.15)

This interest in the vast Sila forest - so far from Rome - only makes sense if Romans were already thinking carefully about the requirements of large-scale naval warfare.

\section{Quaestors and John the Lydian}

If I had been writing this forty years ago, I could have argued that the Romans showed that they were eager to fight at sea as of 267 because it was in that year that they invented four new annual officials called quaestores classici to take charge of their fleet. But I hope that I have demonstrated that there were never any such officials as quaestores classici (they still appear far too often in the scholarly literature, but no one as far as I know has attempted to refute my argument). ${ }^{42}$ That leads me to point out, however, that a crucial text, John the Lydian, De magistratibus 1.27, is virtually never mentioned in the present context. ${ }^{43}$ Now John the Lydian makes a lot of mistakes about the Roman republic, not surprisingly given his circumstances in sixth-century Constantinople and his aims in writing De magistratibus, but he says something very relevant to our purpose: in 267 the Romans prepared a fleet to make war on those who had allied themselves with Pyrrhus, and (with the correct reading of the text) they appointed two 'nauarchs' - presumably, that is to say, duumviri navales classis ornandae reficiendaeque causa - to take charge. John's interest is in the public offices not in the fleet, but his story is credible as far as it goes. Zonaras refers to the same expedition (8.7): he does not tell us whether it was by land or by sea, but he says that punishing the allies of Pyrrhus was only a pretext (and this we can readily believe, since eight years has passed since the Battle of Malventum). What the Romans really wanted, and achieved, was firm control over Brundisium, 'for the place had a fine harbour where it was easy both to sail in from and to sail out to Illyria and Greece' and the same wind allowed you to come in or depart. ${ }^{44}$ All this, of course, was one year after Rome had

${ }^{42}$ W. V. Harris, 'The Development of the Quaestorship, 267-81 вс', CQ 26 (1976), 92-106.

${ }^{43}$ And I did not exploit it enough in War and Imperialism in Republican Rome, 327-70 BC, corrected edn (Oxford, 1985).

${ }^{44}$ See also Florus 1.15. 
shown its interest in the Adriatic by founding a Latin colony at Ariminum. This 267 fleet or flotilla does not appear to have been very large, but it seems to have been Roman, not allied, and it helps to make nonsense of Polybius' legend.

\section{Conclusion}

What happened then in the two generations 321-261 вС? I suggest that Rome started acquiring military shipwrights (perhaps from Naples or Caere) and some triremes by the mid-310s at the very latest. Thus they were able to defend the colony at Pontiae and keep hostile Etruscans at bay. This new state of affairs - Rome as a force to be reckoned with at sea as well as on land - was recognized by Carthage (the treaty renewal of 306) and by Rhodes ('glorious and finest achievements' in the years after 304). This navy did not cease to exist in the 290 s and 280s but it did not see much action. Leading senators knew that war outside the peninsula was coming and were preparing for it from 273 onwards, but Rome was not up to date with the latest developments in warship construction; so c.264 - I do not profess to know when - it had to adapt fairly rapidly to the construction not of its first warships but of quinqueremes.

W. V. HARRIS wvh1@columbia.edu 